\title{
Antegrad Ureteral Stenting; Indications-Methods- Complications and Radiological Approach to Complications
}

\author{
Antegrad Üreteral Stentleme; Endikasyon-Yöntem- \\ Komplikasyonlar ve Komplikasyonlara Radyolojik Yaklaşım
}

Suleyman Bakdik ${ }^{1}$,

Necdet Poyraz ${ }^{1}$,

Cengiz Kadiyoran ${ }^{1}$,

Pinar Diydem Yilmaz ${ }^{1}$,

Mehmet Giray Sonmez ${ }^{1}$,

${ }^{1}$ Necmettin Erbakan University, Meram Faculty of Medicine, Department of

Radiology, Konya, Turkey

Geliş Tarihi/Received: 16 June 2019

Kabul Tarihi/Accepted: 21 December 2019

Address correspondence to: Suleyman Bakdik, Necmettin Erbakan University Meram Faculty of Medicine, Department of Radiology, Konya, Turkey

e-mail: suleymanbakdik@hotmail.com

\section{ORCID}

Suleyman Bakdik

https://orcid.org/0000-0001-9205-4003 Necdet Poyraz

https://orcid.org/0000-0001-9299-189X Cengiz Kadiyoran

https://orcid.org/0000-0002-7173-3530

Pinar Diydem Yilmaz

https://orcid.org/0000-0002-8519-5382

Mehmet Giray Sonmez

https://orcid.org/0000-0003-4615-7348
Öz

Amaç: Bu çalışmanın amacı malign ve benign etyolojilerin neden olduğu üreteral obstrüksiyonların ve üreteral kaçakların tedavisinde antegrad üreteral stentlemenin endikasyonlarını, başarı oranını, komplikasyonlarını, teknik başarıyı artıcak yöntemleri, retrograd ve antegrad üreteral stentlemeye ikincil oluşan komplikasyonların radyolojik yönetimini değerlendirmektir.

Hastalar ve Yöntem: Bu retrospektif çalışmada Ocak 2016 ve Aralık 2018 tarihleri arasında floroskopi ve US rehberliğinde yapılan antegrad üreteral stentleme işlemleri incelendi. Ortalama yaşları 65,87(20-90) olan 25 kadın $(\% 32,05)$ ve ortalama yaşları 68,73(30-90) olan 53erkek $(\% 67,94)$ toplam 78 hastaya 110 adet antegrad üreteral stentleme ve perkütan nefrostomi yapıldı.

Bulgular: Toplam 110 üreteral stent antegrad yolla yerleştirildi. 2 hasta da ise başarısız olundu. Teknik başarı oranımız \%98,21 idi. $15(\% 19,23)$ hastaya uzun örgülü vasküler kılıflar yerleştirildikten sonra stentleme gerçekleştirildi . $2(\% 2,56)$ hastada darlık geçmek için vasküler oklüzyon geçişlerinde kullanılan destek kateter ve rekanalizasyon telleri kullanıldı.

Sonuç: Antegrad üreteral stent yerleştirilmesi, retrograd üreteral stent yerleştirmenin başarısız olduğunda ve zaten perkütan nefrostomi kateteri bulunan hastalarda iyi bir alternatiftir. Yüksek bir teknik başarı oranı ve düşük komplikasyon riski içermektedir.

Anahtar Kelimeler: Duble J üreteral stent, Üreteral obstrüksiyon, Perkütan, Antegrad, Hidronefroz

\section{Abstract}

Aim: The aim of this study is to evaluate the indications, success rate, complications, technical success enhancing method, methods of antegrad ureteral stenting and the radiological management of complications due to retrograde and antegrade ureteral stenting in the treatment of ureteral obstructions and ureteral leaks caused by malignant and benign etiologies.

Patients and Methods: In this retrospective study, fluoroscopy and US-guided antegrade ureteral stenting procedures between January 2016 and December 2018 were examined. The study included 110 antegrade ureteral stenting and percutaneous nephrostomy in a total of 78 patients with 25 female patients $(32.05 \%)$, a mean age of $65.87(20-90)$ and 53 male patients $(67.94 \%)$ with a mean age of 68.73 (30-90).

Results: A total of 110 ureteral stents were placed via an antegrade route. Two patients failed. Our technical success rate was $98.21 \%$. Stenting was performed in $15(19.23 \%)$ patients after long braided vascular sheaths were placed. In $2(2.56 \%)$ patients, support catheter and recanalization wires used in vascular occlusion passages were used to pass stenosis.

Conclusion: Antegrade ureteral stenting is a good alternative for patients with retrograde ureteral stent placement and already with percutaneous nephrostomy catheters. It has a high technical success rate and low complication risk.

Key words: Double J Ureteral stent, Ureteral obstruction, Percutaneous, Antegrade, Hydronephrosis
Cite this article as: Bakdik S, Poyraz N, Kadiyoran C, Yilmaz PD, Sonmez MG Antegrad Ureteral Stenting; Indications-Methods-Complications and Radiological Approach to Complications. Selcuk Med J 2020;36(3): 208-215
Disclosure: None of the authors has a financial interest in any of the products, devices, or drugs mentioned in this article. The research was not sponsored by an outside organization. All authors have agreed to allow full access to the primary data and to allow the journal to review the data if requested. 


\section{INTRODUCTION}

Ureteral stents were first described by Zimskind et al. (1) in 1967 and were used initially for urethral obstruction or fistula treatment. Over time, the indications for ureteral stent placement have increased significantly (2-5). It is now accepted as a standard and indispensable urological tool. Ureteral obstruction is a heterogeneous clinical procedure and its method is difficult to determine. Ureteral obstruction may be due to malignant or benign causes. Malignant ureteral obstruction can be caused by urological malignancies such as prostate or bladder cancer or by any other primary malignancy with gynecological or colorectal origin (6-8). The etiology of benign ureteral obstruction may be intraluminal or extraluminal. Intraluminal causes are the result of a pathology such as ureteropelvic junction obstruction, ureteral stone or ureteral stricture. Extraluminal benign obstruction may result from localized mass effect of benign tumors such as uterine leiomyomas or retroperitoneal fibrosis (9-11). Percutaneous nephrostomy and ureteral stenting are used for the treatment of longterm obstructive uropathy and urinary leakage. Percutaneous nephrostomy is commonly used for the treatment of acute hydronephrosis, aimed at protecting renal function and evacuating infected material. Nephrostomy catheters are uncomfortable for the patient and their complications are infection (12) and displacement of the catheter. In patients without lower urinary tract problems, ureteral stents may alternatively be used for long-term ureter obstruction or fistula treatment. Ureteral stents are usually placed in a retrograde way with cystoscopic guidance. In patients with retrograde localization obstructive malignancy $(13,14)$, it may be difficult to insert the ureteral stent retrogradely in patients with urinary deviation with ileal loop or in patients with transplant kidney due to altered anatomy. Retrograde urethral stent placement is usually performed using spinal and even general anesthesia. General anesthesia has serious complications and may be contraindicated in critically ill patients. In these cases, antegrade percutaneous placement of the ureteral stent into the kidney using fluoroscopic guidance and local anesthesia can be used as an alternative technique.

The aim of this study is to evaluate the indications, success rate, complications, technical success enhancing method, methods of antegrad ureteral stenting and the radiological management of complications due to retrograde and antegrade ureteral stenting in the treatment of ureteral obstructions and ureteral leaks caused by malignant and benign etiologies.

\section{PATIENTS AND METHODS}

After ethics committee approval was taken, between January 2016 and December 2018, fluoroscopy and US-guided antegrade ureteral stenting procedures were reviewed retrospectively. The patients who were evaluated by urologists were not successful or that the retrograde intervention was difficult and unsuitable and general and spinal anesthesia was at high risk. Patients who had no prone position and who had coagulopathy were excluded from the study. The mean age was 65,87 (20-90). 25 female (32.05\%)

Table 1. Indications for ureteral stenting

\begin{tabular}{lll}
\hline Malignancies & 54 & $\% 69,23$ \\
\hline Ovarian carcinoma & 3 & $\% 3,84$ \\
Cervix carcinoma & 2 & $\% 2,56$ \\
Endometrium carcinoma & 1 & $\% 1,28$ \\
Prostat carcinoma & 11 & $\% 14,1$ \\
Bladder carcinoma & 32 & $\% 41$ (Illeal diversion 9$)$ \\
Colorectal carcinoma & 4 & $\% 5,12$ \\
Connective and soft tissue carcinoma & 1 & $\% 1,28$ \\
Benign causes & 18 & $\% 23,07$ \\
Benign prostatic hyperplasia & 2 & $\% 6,41$ \\
Ureteral stenosis & 3 & $\% 3,84$ \\
Neurogenic bladder & 1 & $\% 1,28$ \\
Surgical ligation & 1 & $\% 1,28$ \\
Stone & 11 & $\% 14,1$ (Ureteral leak due to stone \\
Transplante & 4 & $\% 5,12$ \\
Total & 78 & \\
\hline
\end{tabular}


mean age 65.87, 20-90 and 53 male (67.94\%) mean age $68.73,30-90$ totally 78 patients were treated with 110 antegradeureteral stents and percutanous nephrostomy. Demographic data, antegrade ureteral stenting indications, procedure results and complications were evaluated for each patient. The indications for antegrade ureteral stenting are listed in Table 1.

Antegrade urethral stents placed between July 2016 and January 2019 were evaluated retrospectively after ethics committee approval was taken. All procedures were performed by a single interventional radiologist who had an experience of 15 years using an ultrasound and fluoroscopy guidance. The patients were evaluated by urologists. Patients in whom retrograde intervention was not successful or retrograde intervention was difficult and unsuitable, patients with general anesthesia and spinal anesthesia were considered to be at risk. Routine coagulopathy values were checked before the procedure. Patients who had a platelet count greater than 50,000 x10 $3 / \mathrm{LL}(50,000 \times 109 / \mathrm{L})$ and INR lower than 1.5 were patients underwent treatment. All patients underwent local anesthesia and mostly sedoanalgesia. $200 \mathrm{mg}$ i.v. antibiotic prophylaxis with a single dose of ciprofloxacin was given. In our study, we used ureteral stents with a control rope at the two proximal open ends of the antegrade insert (plastimed 7F long-term ureteral stent set and Geotek 7F long-term ureteral stent set).

All patients were hospitalized in the prone position except for patients with transplanted kidney. In patients who had previously undergone percutaneous nephrostomy catheter insertion, nephrostomy was performed, and in the other patients, US-guided kidney was entered into the kidney collector system with a $17 \mathrm{G} 15 \mathrm{~cm}$ needle (Geotek coaxial needle $17 \mathrm{G}$ ) from the upper pole and the mid-cut calyx of the posterior $1 / 3$ of the kidney. After taking some urine, 10cc opaque material (Bayer, Ultravist $300 \mathrm{mg} / \mathrm{ml}$ ) was given and the collecting system was visualized. The hydrophilic wire (Terumo glidewire) was inserted through the needle and a $15 \mathrm{~cm}$ long $8 \mathrm{~F}$ sheath (Cordis Avanti Introducer Sheath $8 \mathrm{~F}$ ) was placed in the renal pelvis. 5F angiographic catheter (Terumo Radifocus Angiographic Catheter) and hydrophilic guidewire and stenosis were reached through the guide wire catheter manipulations. Dilatation was performed with balloon catheters ( $5 \mathrm{~mm}$ or $6 \mathrm{~mm}$ in diameter) in severe stenosis that did not allow stent passage. In cases where the balloon does not respond sufficiently to dilatation and the inclination in the renal pelvis is a problem in stent progression, the $8 \mathrm{~F}$ sheath of $15 \mathrm{~cm}$ length was replaced with $45-60 \mathrm{~cm}$ long $7-8 \mathrm{~F}$ braided sheaths (Cook, Flexor ${ }^{\circledR}$ Ansel Guiding Sheath) provided. After passing the stenosis, the lower end of the stent was first positioned in the bladder, then the upper end was evaluated and the final position of the ureteral stent was given by targeting the renal pelvis. In all cases, 8F nephrostomy catheter (Bioteq Drainage chatheter) was stopped and the procedure was terminated. The nephrostomy catheter was removed under fluoroscopy after the urine lost its hemorrhagic character and became normal and closed for 24 hours and urine output and ureacreatinine levels were monitored.

\section{RESULTS}

A total of 110 ureteral stents were placed in 76 patients, 53 male (\% 67.94), 25 female (\% 32.05) with antegrade route. 55 of the stents were placed to the right, 51 to the left and 4 to transplante kidney. 2 patients failed. While $85.89 \%$ of the patients were included in the study, $11.9 \%$ of the patients underwent stenting via the nephrostomy catheter. For ureteral stent, 54 $(69,23 \%)$ patients had malignancy, $18(23,07 \%)$ had benign causes and $4(5,12 \%)$ had renal anastomosis. Our technical success rate was $98.21 \%$. In a female patient with ureter ligation, the stricture could not be

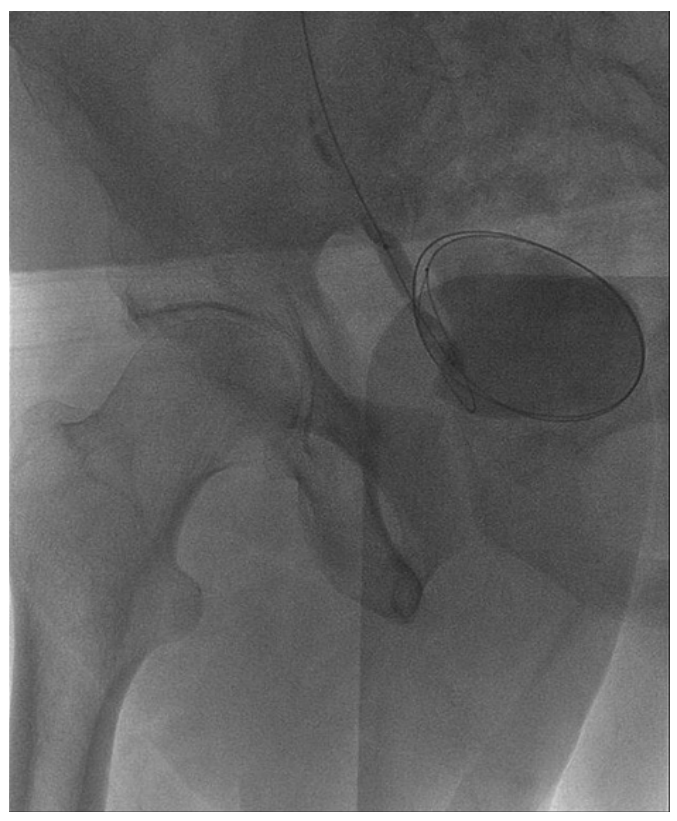

Figure 1. Application of dilatation with balloon catheter at the lower end of the ureter 


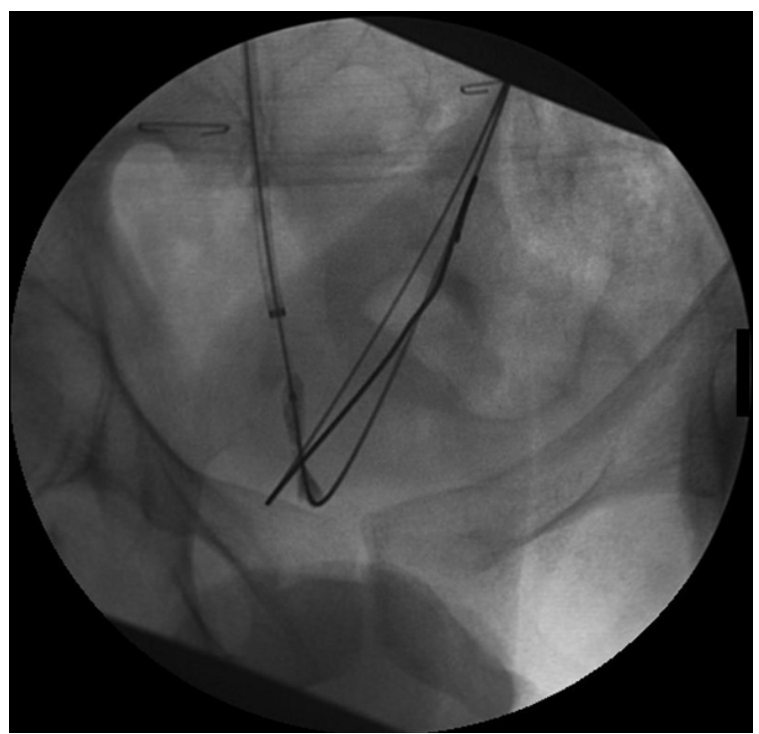

Figure 2. Crossing the stenosis at the lower end of the ureter with long introducer support and dilatation with balloon catheter

crossed. In a patient with urinary perforation during retrograde intervention, a patient with urinoma could not be transferred to the perforation region distal. This patient was not successful in recurrent retrograde procedures and nephrectomy was performed. The ureteral stent of a patient who underwent bladder surgery for a bladder operation could not be placed in the first session, and the patient underwent bolus

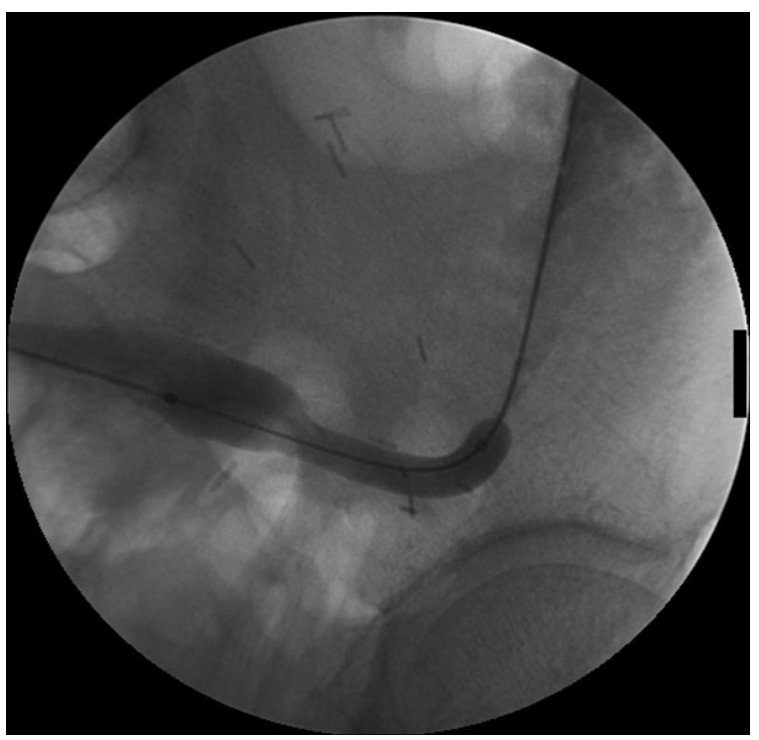

Figure 3a. Balloon catheter application to anastomosis stenosis in a patient with ileal deflection

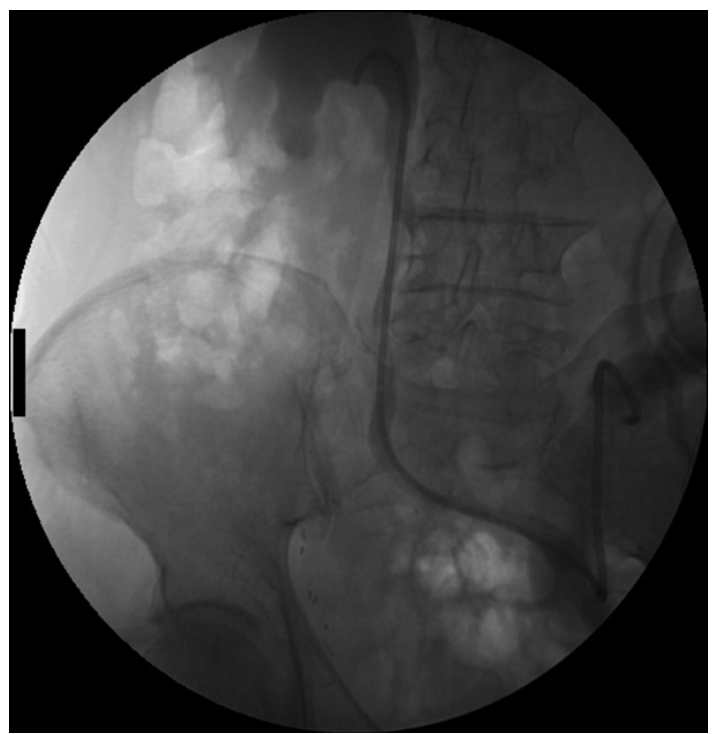

Figure $\mathbf{3 b}$. Insertion of the ureteral stent after dilatation

dilatation with a long braided vascular sheath support. Ureteropelvic stenosis in a female patient with a very large renal pelvis could not be opacified in the first session and the transition to ureteral did not occur. This patient was able to pass the stenosis in the additional session after 1 week.

Balloon dilatation was performed in 30 patients $(38.46 \%)$ who did not allow passage of ureteral stent (Fig. 1). 15 (19.23\%) patients had long braided

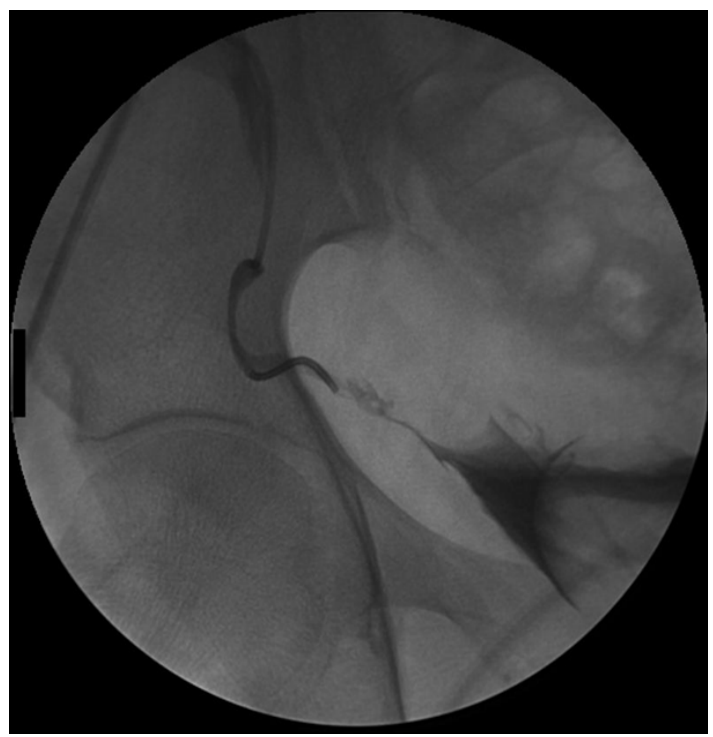

Figure 4a. Anastomosis stenosis at the lower end of the ureter in a transplanted kidney patient 


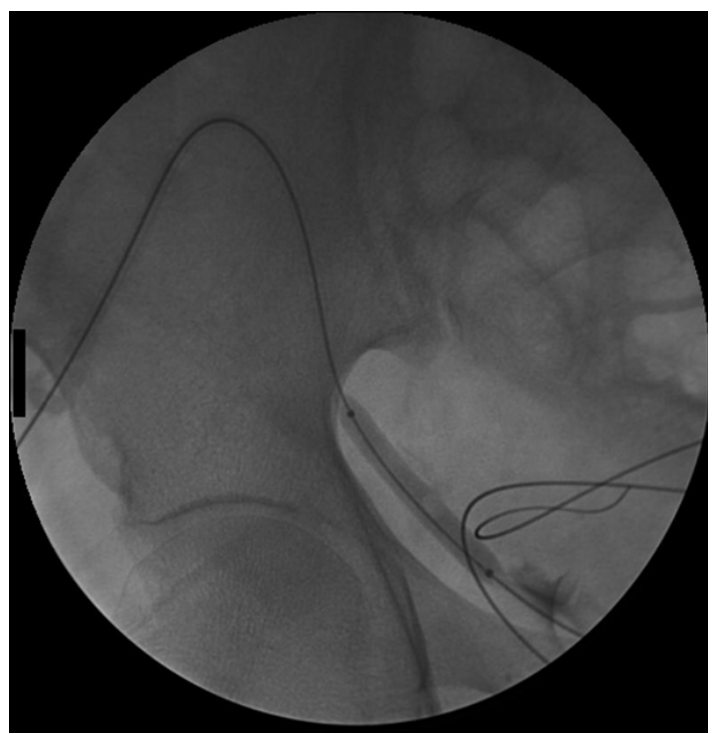

Figure 4b. Dilatation with balloon catheter for anastomosis stenosis

vascular sheaths (Fig. 2). In 2 (2.56\%) patients, the support catheter and recanalization wires used in the vascular occlusion passages were used gently to avoid complications and additional pyelography and urography taken from the vascular sheath after the occlusion was confirmed with no leakage and dilatation with balloon catheters was achieved. Then the soft hydrophilic guiding wire was replaced with rigid hydrophilic wire and the procedure was completed.

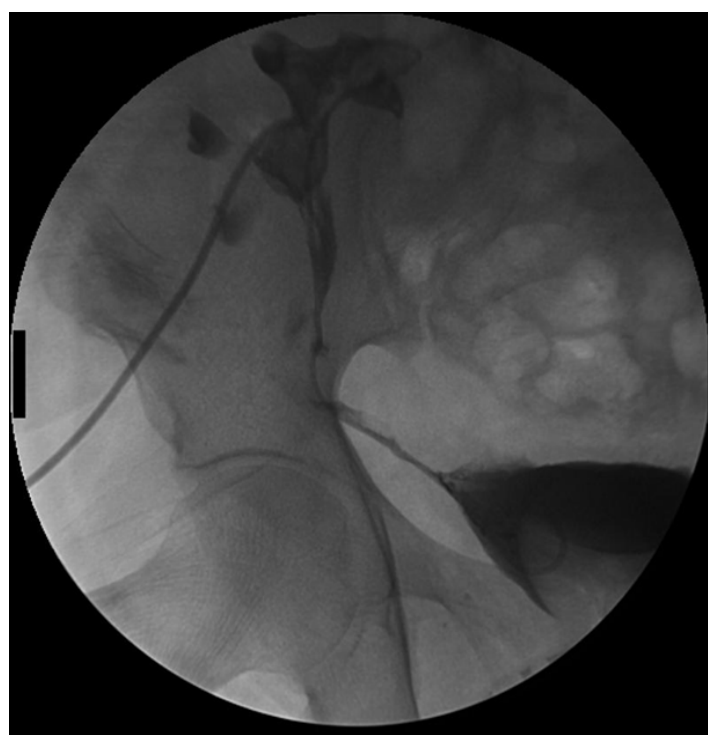

Figure 4c. Placing the ureteral stent and nephrostomy catheter after dilatation

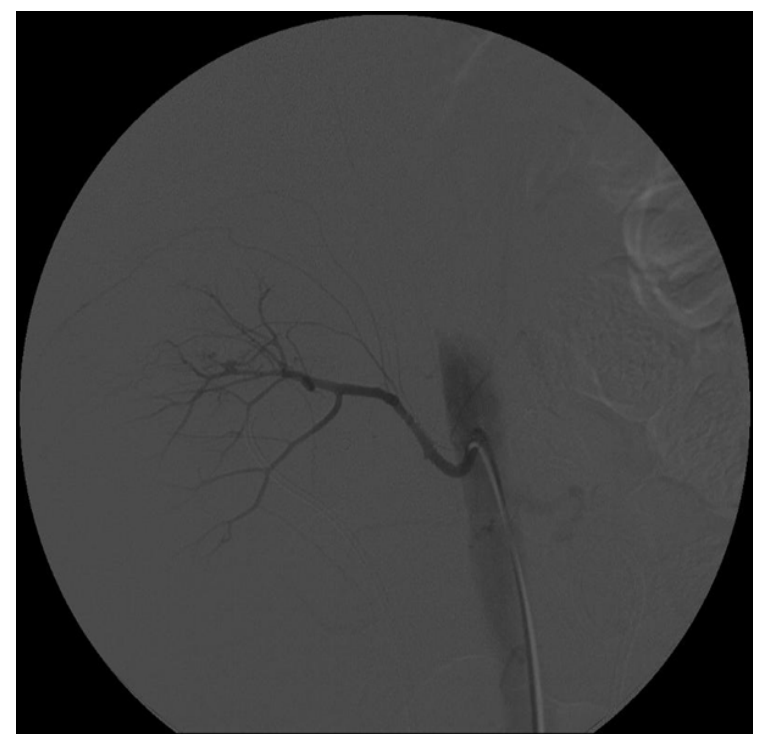

Figure 5a. Contrast-material extravasation in the segmental artery in a patient with hematuria and perirenal hematoma following ureteral stenting

Balloon dilatation was performed on ureteral anastomosis level in 3 of $9(11.53 \%)$ patients with ileal deviation and the catheter tip was brought to the ostomy mouth. The ureteral stent changes of these patients were easily performed retrograde under the

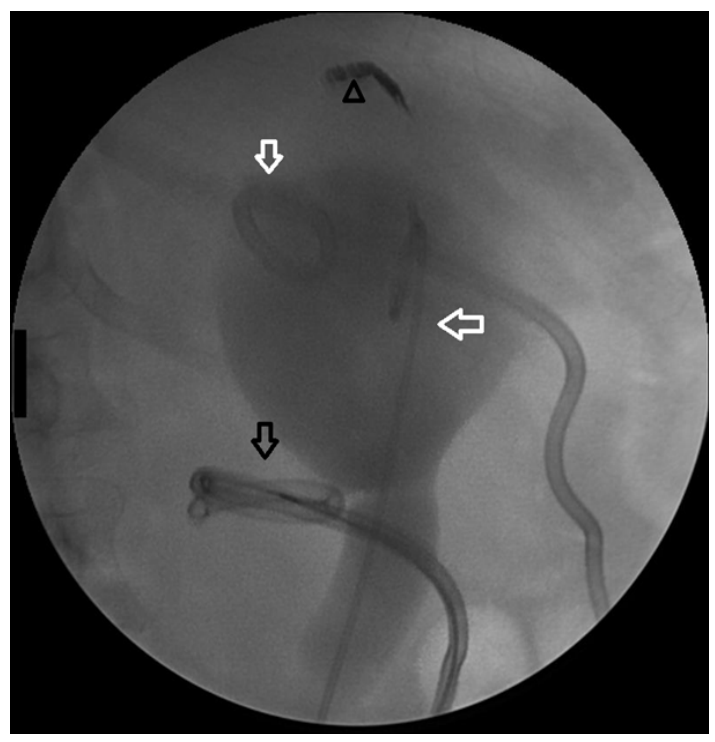

Figure $\mathbf{5 b}$. Embolization of the segmental artery with coils (arrowhead), insertion of the ureteral stent and nephrostomy catheter (white arrows) and percutaneous treatment of the perirenal hematoma by placing the drainage catheter (black arrows) 
guidance of fluoroscopy at the region of ostomy (Fig. $3)$. Four $(5.12 \%)$ patients with renal transplantation underwent ureteral stent placement in supine position. These patients had anastomosis stenosis of the ureter bladder. Urethral stent was placed in the anastomosis area after balloon dilatation in 2 patients.In 11 of our patients, stenting was performed via $14.10 \%$ previously placed nephostomy catheter(Fig. 4).

In one $(1.28 \%)$ patient, the upper end of the ureteral stent was found in the entrance tract of the renal parenchyma. This patient was entered from the bladder under sedoanalgesia and was caught and positioned at the lower end of the stent with the snare catheter. Mild urinary tract infection were observed 7 patients, $(8,97 \%)$ and responded to appropriate antibiotic treatment. Urosepsis was not present in any patient. On one of the patients (1.28\%), 15 days after stent placement, pyelonephritis was seen and percutaneous nephrostomy catheter was inserted and ureteral stent was removed from the bladder by cystoscopy. After the infection regressed, ureteral stent placement was performed via nephrostomy. The limited extravasation of the procedure-related contrast to the perirenal area was seen in $10(12.82 \%)$ patients. It did not require any intervention. 10.8\% of the patients had mild pain or lower urinary tract

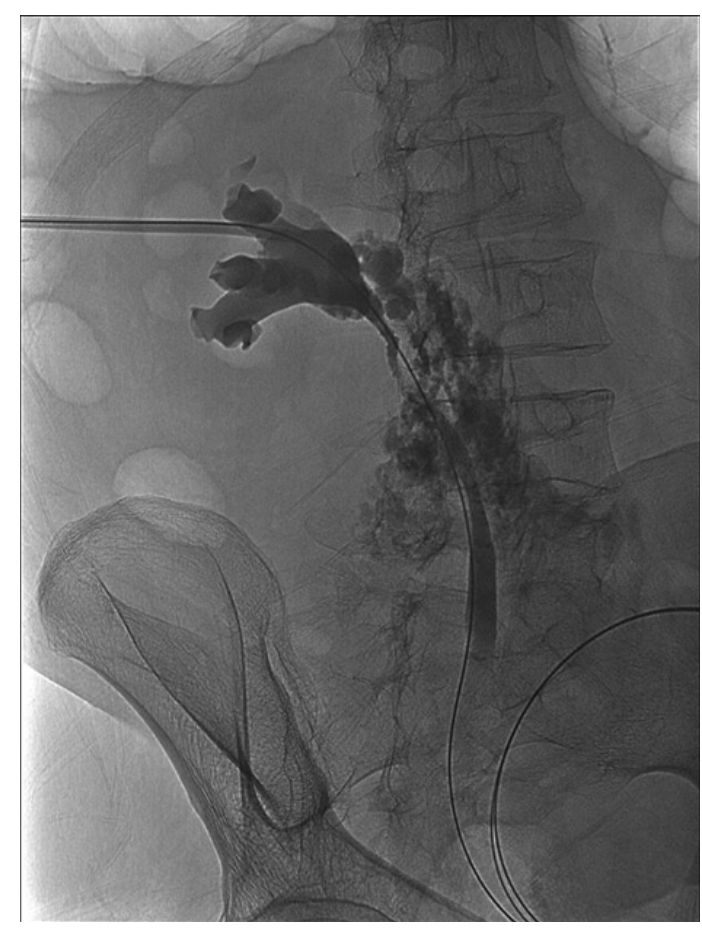

Figure 6a. Extravasation of contrast medium to the retroperitoneal area in a patient with ureter injury

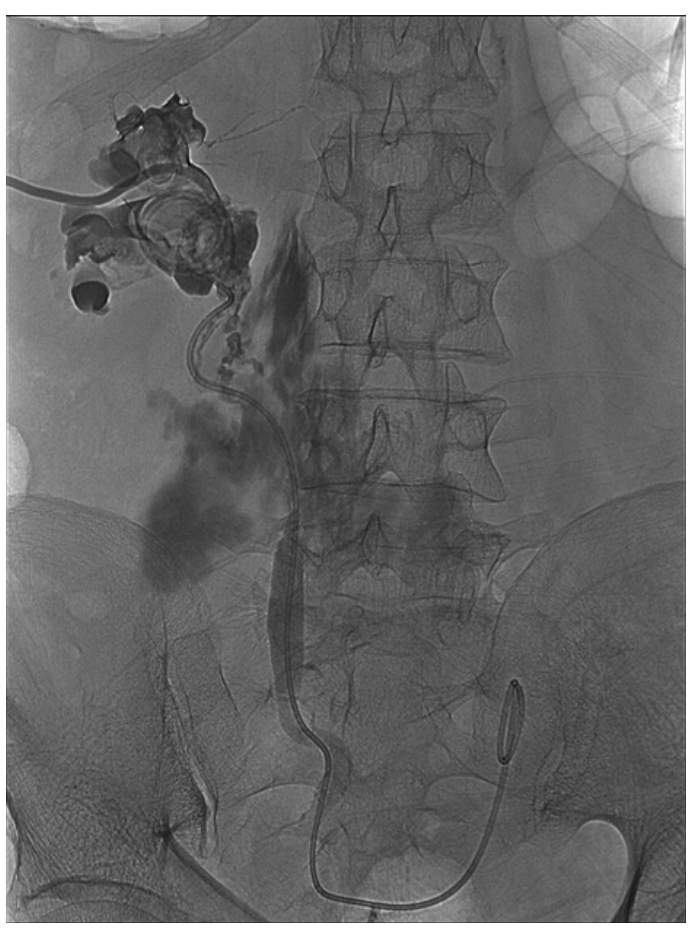

Figure 6b. Ureteral stent and nephrostomy catheter placement to the ureteral injury by antegrade approach

symptoms shortly after the insertion of antegrade ureteral stent. These symptoms regressed with symptomatic treatment (Fig. 5)

Light level hematuria was seen in 55 patients $(70.51 \%)$, and all of our patients had a nephrostomy catheter. In these patients, hematuria spontaneously regressed in a few days, and no hematuria required transfusion or intervention. After ureteral stent placement, one patient $(1.28 \%)$ developed retroperitoneal hematoma on the postoperative night. This patient underwent renal angiography and pseudoaneurysm was shown and bleeding was stopped by embolization with coils. However, in this patient, retroperitoneal hematoma was infected 20 days later and an infected hematoma $14 \mathrm{~F}$ catheter was inserted and percutaneous treatment was performed. Three cases of urinoma due to failed retrograde intervention were treated percutaneously during antegrade stenting (Fig. 6).

\section{DISCUSSION}

The ureteral stents were initially placed in an increasing indication since it was first described in 1967 by Zimskind et al. (1). Ureteral stents are 
usually placed in a retrograde way with cystoscopic guidance. Retrograde stenting has many advantages. It is possible to remove obstructive stones, to take biopsy from malignancies or to widen their strictures. Retrograde ureteral stenting is a one-step procedure and usually requires general or spinal anesthesia and requires operating room facilities. (2-4). It is known that retrograde placement may fail up to $50 \%$ in patients with distal and extra ureteral obstruction caused by malignancies (15). Antegrade ureteral stenting can overcome some of the technical challenges that prevent retrograde stent placement. The success rates in the literature vary between $80 \%$ and $92 \%$. (15-18). In our study, our technical success in ureteral stent placement was 98.21 and was above the literature. One of the advantages of antegrade placement is the passage of ureteral stenosis and occlusions with a low-profile guide wire and angiographic catheter. In addition, the support catheters used to pass vascular stenosis and occlusions, the use of occlusion transition wires as necessary, the long braided vascular sheaths, the extra hard carrier guide wires to provide sufficient support for the advancement of the stent and the expansion of the stenosis with pressureresistant balloons contributed to increase the success of the process according to the literature.

Retrograde placement of a ureteral stent is often performed using spinal or general anesthesia, whereas antegrade ureteral stenting is performed primarily using local anesthesia (15-18). It provides access to patients with percutaneous nephrostomy catheters that simplify the existing procedure and reduce the complication rate (18-20). In our study, antegrade stenting was performed through the present nephrostomy of 11 patients. Percutaneous nephrostomy is usually placed $1 / 3$ posterior inferior to the renal pole. This input may cause problems in passing the stenosis and progression of the ureteral stent due to the angulation of the renal pelvis in antegrade ureteral stenting. We could easily overcome this situation by using braided long vascular sheaths.

Several complications of antegrade ureteral stent placement have been described, including urinary tract infection, malposition, migration, obstruction, accumulation of urine components around the stent, stent fracture and ureteral erosion or fistulization (21). Malposition, hemorrhage, perforation, urinoma, abscess, and pionefrosis can be removed by radiological methods. In our study, the retroperitoneal hematoma unit secondary to antegrade intervention was performed by embolization and the perirenal abscess was removed by percutaneous drainage. In addition, 3 perirenal collections which were formed during the retrograde procedure were treated by placing percutaneous drainage catheters during antegrade intervention. Percutaneous nephrostomy and antegrade ureteral stenting were performed in a patient who had perforation in the ureter during retrograde intervention.

Although antibiotic prophylaxis was applied before the procedure, urinary tract infection was a common complication. The number of absolute infections after antegrade ureteral stent insertion is not available in the literature. Usually, urinary tract infections can be successfully treated with antibiotics. However, it may be necessary to remove the ureteral stent catheter if the infection does not respond to medical treatment. In our study, we removed a ureteral stent at 1 week and placed a nephrostomy catheter. After the clinical and laboratory improvement of the infection findings, antegrade ureteral stenting was performed again on the nephrostomy catheter. Mild haematuria is a common self-limiting finding that may be caused by damaged urothelium shortly after ureteral stent placement. Another hematuria rarely reported, regardless of antegrade or retrograde location, is the fistula between the ureter and an artery. In the literature, the authors report that ureteral stent may be predisposing factors (22). Renal hematuria is frequently encountered during the procedure in ureteral stentings which are started directly without nephrostomy (23). In our study, hematuria was seen in $70.51 \%$ of the patients. For this reason, we have placed the nephrostomy catheter in the entrance tract for 2-3 days. These hematuria spontaneously regressed within a few days, without additional intervention. Our patient with retroperitoneal hematoma had no massive hematuria.

The ureteral stent may be positioned in an unsuitable position. Often this is corrected during the operation, which is noticeable during the process [24]. In our case, we found that the upper end of the ureteral stent was extending from the entrance tract to the parenchyma and we re-positioned the bladder through the urethra and hanging from the distal end with the snare catheter. If the distal end of a catheter is too sagged to the bladder, the proximal end of the stent is not easily separated from the catheter. Alternatively, a wait-and-see policy can be implemented because of the presence of proximal holes. In our study, the distal tip did not hang too much into the bladder. Insertion of a percutaneous nephrostomy catheter helps the ureter 
to heal by decreasing the pressure of the ureter when a ureter perforation is performed (21) In our study, we developed a ureteral perforation during retrograde placement, and we performed a perforation zone and ureteral stenting and nephrostomy placement. However, another patient with perforation could not be transferred to the distal. The guide wire showed a transition from perforation to perirenal collection. In this patient, the transition from the perforation zone was not possible in recurrent antegrade and retrograde interventions and nephrectomy had to be performed.

This study is limited to being retrospective. Therefore, the interventional procedure was not standardized and indications for stenting were heterogeneous.

\section{CONCLUSION}

This retrospective study shows that it is possible to place a ureteral stent percutaneously, with a high technical success rate and a low risk of complications. The use of the equipment used in other radiological procedures in antegrade ureteral stenting increases the technical success. Therefore, antegrade, ureteral stenting is a good alternative in patients with retrograde placement and already with percutaneous nephrostomy catheter. It is possible to manage the complications such as malposition, hematuria, urinoma and abscess perforation by radiological methods. Randomized controlled clinical trials comparing antegrade and retrograde ureteral stent have a limited number of studies, and further studies are needed on the best approach for ureteral stenting.

Conflict of interest: Authors declare that there is no conflict of interest between the authors of the article.

Financial conflict of interest: Authors declare that they did not receive any financial support in this study.

Address correspondence to: Suleyman Bakdik, Necmettin Erbakan University, Meram Faculty of Medicine, Department of Radiology, Konya, Turkey

e-mail: suleymanbakdik@hotmail.com

Phone: 03322236000

\section{REFERENCES}

1. Zimskind PD, Fetter TR, Wilkerson JL. Clinical use of longterm indwelling silicone rubber ureteral splints inserted cystoscopically. J Urol 1967;97:840-4.

2. Seymour H, Patel U. Ureteric stenting: Current status. Semin Intervent Radiol 2000;17:351-65.
3. Mitty HA. Stenting of the ureter. In: Pollack HM, McClennan $\mathrm{BL}$, eds. Clinical urography. 2nd ed. Philadelphia, $\mathrm{Pa}$ : Saunders, 2000; 3186-205.

4. Van Arsdalen KN, Pollack HM, Wein AJ. Ureteral stenting. Semin Urol 1984;2:180-6.

5. Chen ASC, Saltzman B. Stent use with extracorporeal shock wave lithotripsy. J Endourol 1993;7:155-62.

6. Feng MI, Bellman GC, Shapiro CE. Management of ureteral obstruction secondary to pelvic malignancies. J Endourol 1999;13:521-4.

7. Sharer W, Grayhack JT, Graham J. Palliative urinary diversion for malignant ureteral obstruction. J Urol 1978;120:162-4.

8. Holden S, McPhee M, Grabstald $H$. The rationale of urinary diversion in cancer patients. J Urol 1979;121:19-21.

9. Bansal T, Mehrotra $P$, Jayasena $D$, et al. Obstructive nephropathy and chronic kidney disease secondary to uterine leiomyomas. Arch Gynecol Obstet 2009;279:785-8.

10. Fletcher HM, Wharfe G, Williams NP, et al. Renal impairment as a complication of uterine fibroids: A retrospective hospitalbased study. J Obstet Gynaecol 2013;33:394-8.

11. Ormond JK. Idiopathic retroperitoneal fibrosis: An established clinical entity. JAMA 1960;174:1561-8.

12. Bahu R, Chaftari AM, Hachem RY, et al. Nephrostomy tube related pyelonephritis in patients with cancer: Epidemiology, infection rate and risk factors. J Urol 2013;189:130-5.

13. Kaskarelis IS, Papadaki MG, Malliaraki NE, et al. Complications of percutaneous nephrostomy, percutaneous insertion of ureteral endoprosthesis, and replacement procedures. Cardiovasc Intervent Radiol 2001;24:224-8.

14. Chitale SV, Scott-Barrett S, Ho ET, et al. The management of ureteric obstruction secondary to malignant pelvic disease. ClinRadiol 2002;57:1118-21.

15. Uthappa MC, Cowan NC. Retrograde or antegrade doublepigtail stent placement for malignant ureteric obstruction? ClinRadiol 2005;60:608-12.

16. Adamo R, Saad W, Brown D. Management of nephrostomy drains and ureteral stents. Tech Vasc Interv Radiol 2009;12:193-204.

17. Evans PAM, Nisbet AP, Saxton HM. Antegrade ureteric stents in malignant disease. J Intervent Radiol 1988;3:9-13.

18. Sharma SD, Persad RA, Haq A. A review of antegrade stenting in the management of the obstructed kidney. $\mathrm{Br} \mathrm{J}$ Urol 1996;98:511-5.

19. Hackethorn JC, Boren SR, Dotter CT, et al. Antegrade internal ureteral stenting: A technical refinement. Radiology 1985;156:827-8.

20. Lu DS, Papanicolaou N, Girard M, et al. Percutaneous internal ureteral stent placement: Review of technical issues and solutions in 50 consecutivecases. Clin Radiol 1994;49:25661.

21. Dyer RB, Chen MY, Zagoria RJ, et al. Complications of ureteral stent placement. Radiographics 2002;22:1005-22.

22. Darcy M. Uretro-arterial fistulas. TechVasc IntervRadiol 2009;12:216-21.

23. Wah TM, Weston MJ, Irving HC. Percutaneous nephrostomy insertion: Outcome data from a prospective multi-operator study at a UK training centre. ClinRadiol 2004;59:255-61.

24. Rao AR, Alleemudder A, Mukerji G, et al. Extra-anatomical complications of antegrade double-J insertion. Indian J Urol 2011;27:19-24. 